\title{
A STATE JUDGE LOOKS AT THE FEDERAL COURTS *
}

\author{
SAMUUEL J. ROBERTS †
}

There are several good reasons for the increased emphasis currently being placed on federal law, not only by the law schools, the bench and the bar, but by the public as well. Undoubtedly, one of them is the widespread impact that a federal decision, particularly one by our common master, the Supreme Court of the United States, can have on laymen as well as lawyers. This increased concern for federal law highlights the need for communication between the state and federal judiciaries which has been heightened by the rapidly expanding interplay between our two court systems.

Without question, we are in the midst of a period in which courts and their decisions are coming under exceptionally vigorous attack from significant segments of the public. Of course, only a disregard for history could permit one to believe that such attacks are unprecedented, either in their intensity or in the nature of their sources. Merely to recall the era of Chief Justice John Marshall or the days of the Depression is to realize the span of time within which courts generally, and federal appellate courts in particular, have been the object of sustained and angry opposition. No less powerful and popular figures than Andrew Jackson and Franklin Roosevelt have been in the vanguard of such movements.

Notwithstanding the extensive record of conflict aroused by judicial decisions of the past, it is my impression that the controversies swirling about the decisions of the last decade are of a proportion heretofore unequalled. Perhaps this is because, in recent years, judicial decisions have for the first time affected such a variety of sensitive areas-legislative apportionment, racial segregation, religion and the public schools, the rights of indigents accused of crime, to name only the most prominent. Perhaps it is related to the particular stridency, even violence, with which all contemporary issues seem to be debated in the public arena. In any event, it seems to me that the scope as well as the direction of recent attacks on judicial decisions more than

* This article is adapted from a speech delivered by Justice Roberts before the 30th Judicial Conference of the Third Circuit on Sept. 7, 1967 at Atlantic City, New Jersey.

$\dagger$ Justice, Pennsylvania Supreme Court. B.S. 1928, LL.B. 1931, University of Pennsylvania. Member, Pennsylvania Bar. 
ever before poses singular dangers to the tradition of judging and constitutional interpretation as we have known and practiced it.

These dangers arise from the persistent suggestion of certain groups and individuals dissatisfied with particular decisions to so restrict the adjudicatory process that constitutional and legal interpretations, contrary to their views, will be foreclosed. Without intimating one's own philosophical preference among substantive choices, I think most of us would agree that the effectuation of such restrictions ultimately would deprive our nation of a process which has proved to be both a bulwark of liberty and a unique source of creative progress.

In the face of these dangers, it is imperative that judges avoid conduct and pronouncements which detract from public understanding of either the proper amplitude or the proper limitations of the judicial process. Especially is this so in the context of relations between state and federal courts, where the overlapping competences of independent tribunals continually create temptations for unwise and intemperate judicial responses.

Certainly, then, it is regrettable when some state judges conjure up imagined slights to the dignity of state court systems as an excuse for urging the kinds of restrictions on the operations of the federal judiciary which will impede the prompt implementation of federal rights. Unfortunate too is the spectacle of judges who vent their displeasure with one recent decision or another, by soliciting legislative tampering with the operation of the judicial process and the principle of separation of powers. It is also upsetting to witness the behavior of judges whose ideological persuasions so overpower their sense of restraint and propriety that we find them repeatedly joining one side or another in debates on substantive issues which are later bound to come before their courts in the form of litigation. In this regard, I think the courage and restraint recently displayed by Mr. Justice Marshall before the Senate Judiciary Committee is a good example from which we could all profit.

What particularly concerns me about the indiscretions I have just catalogued is that they give credence to the mistaken, but nonetheless widespread, belief that recent interpretations of our constitutions and laws constitute a usurpation of authority by judges. This notionthat recent decisions somehow indicate a departure from established and accepted practices of judging-is of course a prime source of the misguided proposals which seek to interfere with the tradition of our judicial function.

When judges themselves cast aspersions on their colleagues' stewardship of the judicial process, is it any wonder that large seg- 
ments of informed lay opinion are led to unfortunate conclusions? Moreover, is it any wonder that individual lawyers, as well as the organized bar, are reluctant to intervene by coming to the defense of a judiciary whose less disciplined members constantly substitute judicial tantrums for mature, constructive disagreement. The very first canon of professional ethics recites that: "Judges, not being wholly free to defend themselves, are particularly entitled to receive the support of the Bar against unjust criticism and clamor." But these will remain mere words on paper unless and until the bench, by its responsible conduct, earns the support of the profession, and thus breathes life into them. Lest I be misunderstood, let me point out most emphatically that I do not suggest curtailing or lessening the proper expression of divergent views among judges. I only suggest that these differences of opinion be aired in appropriate forums and in a more objective, more scholarly, more constructive and less theatrical manner.

Perhaps all of us would do well to bear in mind the words of $\mathrm{Mr}$. Justice White at this year's Conference of Chief Justices. Speaking of Miranda, in which he dissented, Justice White noted that although the correctness or wisdom of that decision may be sincerely open to question, that "in terms of the function which the Court was performing" there was "little difference between Miranda and several other decisions, some old, some new, which have construed the Fifth Amendment in a manner in which it has never been construed before, or as in the case of Miranda, contrary to previous decisions of the Court and of other courts as well." I would further echo Mr. Justice White's thesis in that speech that there is "little reason for the judiciary to apologize for doing as best they can the very job which they are bound to do." 1

It is imperative not only to preserve public confidence, but also for the very integrity of the judicial process itself, that men of the bench engage in a responsible dialogue, particularly between members of the state and federal systems. This is so because the federal and state courts, while sitting in different chambers, nevertheless occupy courtrooms that are connected by a swinging door of legal principles which has been propped open by such landmark decisions as Erie Railroad ${ }^{2}$ and Mapp v. Ohio. ${ }^{3}$

A natural by-product of two independent, but at the same time interdependent, judicial systems, has been a certain amount of tension which began in the days of Sreift v. Tyson, ${ }^{4}$ when the door between the

1 Address by Honorable Byron R. White, Justice, Supreme Court of the United States, Nineteenth Annual Conference of Chief Justices, Aug. 3, 1967.

2 Erie R.R. v. Tompkins, 304 U.S. 64 (1938).

3367 U.S. 643 (1961).

441 U.S. (16 Pet.) 1 (1842). 
courtrooms was tightly locked. The tension resulting from the absence of a uniform common law within a given state was obvious. How frustrating it must have been for my predecessors to see established principles of state common law swept aside by federal decree, simply because one of the parties resided in another jurisdiction. In 1938, all this was changed by a trespasser named Tompkins. A principal motivation for the Erie decision was a desire to see litigants treated equally, regardless of their choice of forum, thus resulting in an opening of the door between our courtrooms, and causing many observers of the federal system to feel that the Erie decision also would eliminate a great deal of the tension between state and federal courts. This hope has been realized to a considerable degree, although the distinction between procedural and substantive rights still poses many thorny problems.

Of course there was always the possibility that the tension formerly caused by lack of communication and two separate bodies of law would become instead a tension caused by too much communication and a single body of law. There was always the possibility that the federal courts would resent being forced to bow to the state court's interpretation of the common law, thereby in a sense becoming yes men, instead of judicial innovators. But neither of these possibilities came to pass, undoubtedly because federal judges recognized that the judicial system functioned more smoothly when the law was indeed common to all. Moreover, federal interpretation of state law in diversity cases often has proved to be useful precedent within the state system itself.

So we must not forget, amidst the steady outpouring of critical articles in newspapers, magazines and professional journals aimed at the Supreme Court's alleged usurpation of state court functions, that it was the federal judiciary which first passed through the swinging door to borrow lawbooks from their state court colleagues. The federal courts' reaction to Erie could well be mirrored by state judges who are currently faced with the myriad of Supreme Court decisions interpreting the fourteenth amendment. Just as the federal judiciary realized that within a given state the common law should be uniform as to all litigants, so also should we of the state judicial system accept the principle, now firmly established by such cases as Malloy v. Hogan ${ }^{5}$ and Pointer $v$. Texas, ${ }^{8}$ that with respect to certain procedural requirements of due process, the entire nation is but "one state." In the words of the Malloy Court, it would be "incongruous" to have the 
extent of these fundamental rights affecting individual liberties depend upon the peculiarities of a particular jurisdiction. ${ }^{7}$ Although all of us are acutely aware that the absorption of many of the guarantees of the Bill of Rights into the fourteenth amendment in recent years has placed a tremendous strain on our judicial resources, "we cannot sacrifice to mere expediency the wise restraints and constitutional safeguards which make men free and advance the quality of criminal justice." 8

The result of this evolution in criminal procedure-and I deliberately chose the word evolution rather than revolution-is that while the states continue to serve as laboratories of experimentation, insofar as these personal liberties are concerned, they must take their cue from the Supreme Court of the United States. Of course, this is not to say that state judges must put on a set of federal blinders that permits them only to read the Supreme Court reporter and then react like well programmed computers. Witness the landmark decision in Mapp v. Ohio. ${ }^{.}$Lay criticism notwithstanding, Mapp was not an arbitrary insistence that Ohio apply the federal exclusionary rule in search and seizure cases. Instead, the Supreme Court examined quite closely the states' experience with illegal search and seizure as the doctrine had been applied since $W$ olf $v$. Colorado, ${ }^{10}$ and concluded that the federal exclusionary rule was to be appended to the $W$ olf holding only because the states had proved unable to institute suitable alternatives. I think it can be said fairly that had the Court in Mapp been shown a viable alternative, it would not have felt compelled to insist that the states adopt the federal exclusionary rule. Moreover, the rationale of Mapp is largely grounded on Mr. Chief Justice Traynor's opinion in People v. Cahan, ${ }^{11}$ which declared that California would apply the exclusionary rule, thus demonstrating that the Supreme Court can be sensitive as well as responsive to the thought of state judges on constitutional issues. This cooperation shows every evidence of being continued. For example, the recent decision of In re Gault, ${ }^{12}$ while setting forth certain basic rights which must be afforded to juveniles, purposely leaves many questions unanswered. Although the Court someday may be forced to decide these questions, in the interim the field remains open for state court interpretations which very well may guide the Supreme Court when it eventually speaks.

7 Malloy v. Hogan, 378 U.S. 1, 11 (1964).

8 Commonwealth ex rel. Butler v. Rundle, $416 \mathrm{~Pa}$. 321, 330, 206 A.2d 283, 288 (1965).

9367 U.S. 643 (1961).

10338 U.S. 25 (1949).

1144 Cal. 2d 434, 282 P.2d 905 (1955).

12387 U.S. 1 (1967). 
A few moments ago I indicated that state judges could learn a valuable lesson in inter-judiciary diplomacy from our federal colleagues and their decision in Erie. However, I think it only fair to note at least one salient distinction between the Erie experience and the problems posed to state judges in the area of criminal law and the federal constitution. When state law appears in the federal arena, it most often enters through the door marked diversity or, perhaps, pendant jurisdiction. Having entered through this door, it cannot return, at least as part of the same case, except perhaps in those rare instances where the abstention doctrine is invoked. On the other hand, the remedy of federal habeas corpus often gives a federal court an opportunity to review the very case decided previously by a state tribunal. I am sure that federal judges can appreciate the feelings of a state judge or an appellate court whose opinion is "reversed" by a federal habeas court; and I am sure precisely because you and your colleagues have demonstrated this appreciation on numerous occasions, notwithstanding some suggestions to the contrary. As Judge Craven warned in his opinion in Patton $v$. North Carolina, ${ }^{13}$ decided while he still was sitting on the district court: "No one-judge federal district court ought to lightly entertain an invitation to reject the considered judgment of his state's highest court on any question of law-constitutional or otherwise." That this warning has been heeded by most, if not all, of Judge Craven's colleagues is amply demonstrated. In the last five years, of the more than 10,000 federal habeas petitions filed by state prisoners, less than 1.5 per cent of the petitioners have been successful, a result which stems at least in part from deference to state decisions.

I realize, as I am sure you do also, that the state court fear of habeas reversal is magnified by the seemingly awesome power given to one federal judge to reverse seven members of a state's highest court, or at least, in the case of my Court, four members, given the rare instances of unanimity. Yet, in fact, such a magnification is no more warranted than the basic fear itself. The federal judge certainly does not have the final say in a federal habeas case. He will not, by his own hand, turn convicted state criminals loose. To be sure, the federal highway from state jail to freedom is a turnpike with many a toll booth for the hopeful inmate. Taking my cue once again from Judge Craven, let me refer to his well reasoned and no doubt accurate timetable for federal habeas relief.

There must first be a declaration of constitutional law by the state supreme court with denial of relief to the state prisoner. Second, a 
writ of habeas corpus will be filed in a federal district court which in turn will grant the writ and command the release of the prisoner, both contrary to the decision of the state supreme court. Third, the prosecutor will appeal this decision to the appropriate circuit court of appeals, following which, fourth, the district court will, on motion, presumably stay its order until the appeal can be heard and determined. If the district judge fails to stay his own order, the appropriate circuit court of appeals can be petitioned by the state to do so. The fifth step will involve a decision by the court of appeals either reversing the district judge and agreeing with the state supreme court, or affirming the district court. In the latter event, the sixth step will be taken, a petition for certiorari by the state prosecutor to the Supreme Court of the United States on the ground of conflict between a state supreme court and a circuit court of appeals.

Finally, as a postscript to this extensive list of substantive as well as procedural hurdles, I need mention only briefly a fact that is no doubt obvious to all of us; even the very issuance of a passport for a federal habeas journey requires a showing by the petitioner that he has exhausted all his state court remedies, both direct and collateral. As $I$ indicated in a speech delivered two summers ago to the Philadelphia Bench-Bar Conference, ${ }^{14}$ I personally believe that this last hurdle ought to be the highest one of all. But it only can be made so if the state courts do not withdraw from habeas corpus. It will not do for a state judge to conduct a perfunctory habeas hearing, render a hasty decision and supplement it with a cryptic record, all in the belief that Torensend $v$. Sain ${ }^{15}$ will act as a panacea for all constitutional ills. And this becomes especially true when it is remembered that these same judges are often the very ones who most decry the intervention of the federal courts into their judicial backyard. The passport to a federal habeas journey ought to contain more-much more-than a rubber stamp which says merely "conviction upheld." Neither federal judges nor state appellate judges can render effective justice without a complete state court habeas record which demonstrates a sensitivity to the manifold constitutional issues presented in practically every petition. There is no reason whatsoever why state and federal habeas relief should not be coextensive; and it is my sincere hope, and belief, that Pennsylvania's new Post Conviction Hearing Act ${ }^{16}$ and some recent decisions of my Court ${ }^{17}$ will bring about this harmony.

14 This speech is reprinted under the title Expanding Professional Responsibilities in the Field of Criminal Lare, 37 PA. BAR Ass'N Q. 222 (1966).

15372 U.S. 293 (1963).

16 PA. Stat. ANN. tit. 19, $\$ 1180-1$ to -14 (Supp. 1966).

17 See, e.g., Commonwealth v. Snyder, $427 \mathrm{~Pa} .83,233$ A.2d 530 (1967) ; Commonwealth ex rel. Washington v. Maroney, $427 \mathrm{~Pa}$. 599, 235 A.2d 349 (1967). 
Unfortunately, for me at least, the battle will not be completely won until our state trial judges also, if you will excuse the pun, set the record straight. It has been most disturbing of late to see many of our direct appeals, particularly in the difficult areas of guilty pleas and waiver of the right to appeal, come to us with totally inadequate trial records, thus often compelling our Court to remand for further hearing, placing an additional unnecessary burden upon our judicial machinery. ${ }^{18}$ Perhaps, however, the same broom that should sweep clean our state habeas proceedings under the new act and the decisions of my Court will also tidy up the trial records as well.

Of course it would require the naìveté of an over-eager first year law student to conclude that the federal and state judiciaries consistently maintain a level of intellectual harmony equal to the good fellowship of a boy scout jamboree. True, there may not be the open warfare that some bemoan; but nonetheless, occasional border skirmishes occur. For example, I refer to United States ex rel. Russo v. New Jersey ${ }^{10}$ particularly the divergent views taken by New Jersey and Pennsylvania as a result of that decision. ${ }^{20}$ And yet, even what appears on its face to be an expression of disagreement between federal and state courts often can emerge as an act of comity between the systems which reasonably could be expected to unify the law. For example, my Court recently had before it a case involving an attack on the voluntariness of a confession by a defendant who had pled guilty at trial. ${ }^{21}$ In spite of the rule that a guilty plea acts as a waiver of all nonjurisdictional defenses, the argument was made before us that the guilty plea would never have been entered but for the now challenged confession. In deciding this case, we were presented with an able opinion by a member of this circuit, the underlying rationale of which pointed to a rule of law permitting such attacks to be made. ${ }^{22}$ Because of my high regard for the competency of the federal judiciary, it was only after considerable research and extensive thought and rethought that I suggested a different rationale which was adopted by my Court. I firmly believe that more than a modicum of good has come from this healthy difference of opinion. Not only did the district judge involved make the appellant's argument much better than the brief was able to do, but now, should the Third Circuit ever face the

18 See, e.g., Commonwealth ext rel. Fink v. Rundle, 423 Pa. 133, 222 A.2d 717 (1966); Commonwealth ex rel. West v. Myers, 423 Pa. 1, 222 A.2d 918 (1966).

19351 F. 2d 429 (3d Cir. 1965).

20 Compare State v. Coleman, 46 N.J. 16, 214 A.2d 393 (1965), with Commonwealth v. Negri, 419 Pa. 117, 213 A.2d 670 (1965).

21 Commonwealth v. Garrett, 425 Pa. 594, 229 A.2d 922 (1967).

22 United States ex rel. Cuevas v. Rundle, 258 F. Supp. 647 (E.D. Pa. 1966). 
problem, it will be aided, I hope, by two opinions presenting both sides of the coin.

$U_{p}$ to now I have confined my remarks almost entirely to areas of constitutional, and more particularly, criminal-constitutional law. However, my general thesis, that keeping the door between the courtrooms open not only will minimize the friction between federal and state judiciaries, but also will result in more equal treatment of litigants, has just as much vitality in non-constitutional, non-criminal areas. Easily the most significant step yet taken toward establishing a uniform interpretation of state law by federal and state courts has been Florida's unique certification procedure. ${ }^{23}$ Under the Florida statute, as supplemented by rules of court, a federal appellate court may certify questions of state law to the Florida Supreme Court. This tribunal then receives briefs, hears argument on the question and, in an opinion, decides the certified question. These opinions, I might add, have not been devoid of some judicial whimsy. As my namesake, Justice Roberts of the Florida Supreme Court, quipped in Aldrich v. Aldrich: "We appreciate the courtesy of the Supreme Court of the United States in allowing this court to participate in the settling of an important principle of state jurisprudence." 24

Since the initial decision to employ Florida's statute rests with the federal appellate court, the certification procedure clearly can be only as effective as the federal judiciary chooses to make it. The Florida procedure has in fact been infrequently employed-perhaps too infrequently. This very well may be due either to the clarity of Florida law, or to a reluctance on the part of the Fifth Circuit Court of Appeals to burden a state tribunal already saddled with more litigation than it can handle efficiently. Although I believe that the certification procedure should not be invoked indiscriminately, certainly when a previously undecided state question of significant import finds its way into the federal system, certification to the state court will preserve the integrity of local law and forestall a possible conflict with later state decisions.

I realize that ordinarily this suggestion would be better directed toward a legislature which certainly could adopt a procedure similar to Florida's. However, I suspect that state courts themselves, in those jurisdictions unhampered by a case or controversy constitutional provision, could probably accomplish the same result by rule of court. The certification procedure would be of equal utility to state appellate courts confronted with significant, unresolyed questions of non- 
constitutional federal law, although I am fully aware that such a procedure might not be permissible under the case and controversy provision of the federal constitution.

As Mr. Justice Brandeis counseled in Erie Railroad v. Tompkins, the line between substance and procedure is a difficult one to draw. Nevertheless, I shall attempt to draw it here for limited purposes. Specifically, I now would like to shift my focus from the substantive interplay between state and federal courts to some of the more mechanical aspects of court procedure. One of the advantages of our two separate judicial systems is the ability of each to experiment with various techniques designed to improve the quality and efficiency of judicial determinations. Each system can then glean from the other what can best be adapted to its own particular problem.

While I by no means feel that these examples are exhaustive, two instances in which a state court could profitably borrow from the federal experience come to mind. The federal system, realizing the presence of an untapped judicial resource in the persons of its retired district and circuit judges, has for many years profitably employed a senior judge system. A Pennsylvania analog, adapted to Pennsylvania needs, now exists. Pursuant to a constitutional amendment ${ }^{25}$ and a recently enacted statute, ${ }^{28}$ retired judges with ten years of judicial experience who have not been defeated for re-election may be recalled by my Court to serve temporarily in any judicial district.

The second example has not yet become reality, although a substantial number of the members of both our bar and bench advocate its adoption. Following the lead of the court of appeals, I suggest now, just as I have on previous occasions, that the Pennsylvania Superior Court be expanded by the addition of two judges so that most appeals to it can be heard by one of three three-judge panels. It has long been recognized in Pennsylvania that the Superior Court is our most overburdened tribunal. If the Superior Court were to sit en banc only in those appeals it deems most important, the time required by each of its judges to hear and consider cases would be reduced by about two-thirds, since each judge would sit on only about one-third of the total appeals. The time thus saved could be devoted by each Superior Court judge to deciding some of the appeals which now come directly to the Supreme Court, thereby enabling our whole appellate system to meet in a reasonable manner the quantitative assault on the quality of judicial determinations. Furthermore, the panel system would facilitate expansion of the senior judge program to utilize retired Superior Court judges as well. 
Lest it be thought that the state system is devoid of significant innovations, I suggest that Pennsylvania is a pioneer among states in its use of lawyer-arbitrators to decide smaller claims. A not insubstantial portion of federal district court litigation involves claims where the amount in controversy is sufficiently small that the Pennsylvania arbitration panel system could serve as a model for expeditious disposition of these suits.

I have heretofore stressed the interplay, both substantive and procedural, between the state and federal systems. Nevertheless, a complete identity of systems would sap the strength of both. Differing backgrounds and perspectives brought by federal judges to diversity litigation and by state judges to non-constitutional federal issues often inject into both state and federal law an inventiveness and vitality which insures that neither body of law will become stagnant by settling in an undisturbed pond. Properly viewed, what may at some moment appear to be a conflict between our court systems, in reality, is not a conflict at all, but rather the contribution of each system toward the attainment of the American ideal of equal justice for all in a mature and free society. Perhaps this goal would be more easily reached if all cases presented solely either federal questions or state questions. But, that would be a storybook world indeed.

Three years ago, in a memorable address before the Conference of Chief Justices, Mr. Justice Brennan eloquently yet succinctly stated the issue confronting all of us here today. I think it only appropriate to close with his words. "The time has come, I think," Justice Brennan said, "to recognize fully that, while our functions are different and while our decisions must sometimes disagree, we are nevertheless all engaged in administering the law of the same nation." 27

27 Address by Honorable William J. Brennan, Jr., Justice, Supreme Court of the United States, Sixteenth Annual Conference of Chief Justices, Aug. 7, 1964, reprinted as Brennan, Some Aspects of Federalism, 39 N.Y.U.L. REv. 945 (1964). 